\title{
anu \\ Optimization of Valorization of Chicken MDCM to Produce Soluble Protein and Collagen Peptides
}

\author{
Nora Pap ${ }^{1}$, Sari Mäkinen ${ }^{1}$, Ulla Moilanen ${ }^{2}{ }^{\mathbb{D}}$, Marjatta Vahvaselkä ${ }^{3}$, Jyri Maunuksela ${ }^{3}$, Maritta Kymäläinen ${ }^{2}$ \\ and Anne Pihlanto ${ }^{1, *}$ \\ 1 Natural Resources Institute Finland, Production Systems, Myllytie 1, 31600 Jokioinen, Finland; \\ nora.pap@luke.fi (N.P.); sari.makinen@luke.fi (S.M.) \\ 2 HAMK Bio Research Unit, Häme University of Applied Sciences, Visamäentie 35 B, 13100 Hämeenlinna, Finland; \\ ulla.moilanen@hamk.fi (U.M.); maritta.kymalainen@hamk.fi (M.K.) \\ 3 Natural Resources Institute Finland, Production Systems, Latokartanonkaari 9, 00790 Helsinki, Finland; \\ marjatta.vahvaselka@luke.fi (M.V.); jyri.maunuksela@luke.fi (J.M.) \\ * Correspondence: anne.pihlanto@luke.fi; Tel.: + 35-82-9532-6438
}

check for updates

Citation: Pap, N.; Mäkinen, S.; Moilanen, U.; Vahvaselkä, M.; Maunuksela, J.; Kymäläinen, M.; Pihlanto, A. Optimization of Valorization of Chicken MDCM to Produce Soluble Protein and Collagen Peptides. Appl. Sci. 2022, 12, 1327. https://doi.org/10.3390/ app12031327

Academic Editor: Vincenza Ferraro

Received: 3 December 2021

Accepted: 17 January 2022

Published: 26 January 2022

Publisher's Note: MDPI stays neutral with regard to jurisdictional claims in published maps and institutional affiliations.

Copyright: (C) 2022 by the authors. Licensee MDPI, Basel, Switzerland. This article is an open access article distributed under the terms and conditions of the Creative Commons Attribution (CC BY) license (https:// creativecommons.org/licenses/by/ $4.0 /)$.

\begin{abstract}
This study aimed to utilize enzymatic treatment and pressurized hot water extraction (PHWE) to recover soluble food-grade protein and collagen peptides from mechanically deboned chicken meat (MDCM), a side-stream from the meat industry. Food-grade enzyme blends Ermitase 1 and Ermitase 2 were used to fractionate the mechanically deboned meat into fat, soluble protein, and solids. Response surface methodology was utilized to optimize treatments to maximize the protein yield. At the optimum conditions (hydrolysis time $240 \mathrm{~min}$, E:S 0.27\%, and a hydromodule $1 \mathrm{~L} / \mathrm{kg}$ ), the enzymatic treatment produced high protein yield, approximately $90 \%$. The protein hydrolysates showed a good solubility index, but weak gelling properties. The PHWE of the bones resulted in a high nitrogen yield, approximately $87 \%$, at the optimum conditions of $190{ }^{\circ} \mathrm{C}$ and $83 \mathrm{~min}$. Peptides in the bone extract were in the range of 0.5-13.7 kDa. Overall, our study highlights the importance of response surface methodology to optimize parameters for mechanically deboned chicken meat enzymatic and PHWE treatments to achieve high yields of protein for food applications and low-molecular-weight collagen peptides for cosmetic applications. The crucial role of protein and peptide prices was observed in preliminary profitability analysis.
\end{abstract}

Keywords: MDCM; enzymatic treatment; pressurized hot water extraction; soluble protein; collagen peptides

\section{Introduction}

The production and consumption of poultry products have increased globally. Statistics from poultry industry have shown that the United States, China, and Brazil have maintained their positions as the largest producers of poultry meat. With this high production, thousands of tons of byproducts in the form of viscera, feet, head, bones, blood, and feathers are generated [1]. The viscera constitute about $30 \%$ of these wastes, while feathers can be up to $10 \%$ [2,3]. The filleting step generates a byproduct known as keel bone cartilage during the processing of the chicken carcass, which is defined as a flexible cartilage that connects the breast muscle of the chicken to the tip of the sternum. This cartilage is simply discarded from the carcass after removal of the breast fillets, even though it is rich in collagen and an added value compound for biochemical and biomedical applications $[4,5]$. MDCM is a paste-like meat product produced by forcing ground chicken under high pressure through a sieve to separate the bone from the edible meat tissue [6]. The resulting product is a blend primarily consisting of tissues not generally considered meat, such as bone, cartilages, skin and the scraps of meat remaining on the bones. Generally, MDCM is high in lipid and ash content, and it contains more free heme groups than the 
fresh meat [7]. Due to the inexpensive cost and high nutritional value, MDCM is a potential sustainable source of meat protein for food applications.

Despite its good nutritive properties being suitable for people on gluten-free and keto diets, MDCM is still underutilized [8]. The same authors described high-pressure homogenization as a novel trend for meat and fish byproduct valorization for functional ingredients.

However, further processing is needed to meet the requirements of regulation and sensory properties regarding food use. Collagen is a major structural protein in connective tissues of bone, tendon, and skin. In the form of small peptides, it is commonly used in cosmetic applications and nutraceuticals [9].

Enzymatic hydrolysis is a promising technology for converting the meat industry byproducts into food-grade ingredients through producing hydrolysates rich in nutrients and suitable functional properties. Mokrejš et al. [10] described MDCM as a potential material for producing gelatin through enzymatic treatment as a conditioning step, and by implementing experimental design, these authors could describe the optimum conditions of processing to achieve high conversion rates (30-32\%) and functionality, such as gel strength.

The properties of the hydrolysates can be adjusted by choosing appropriate enzymes and varying processing parameters such as the enzyme-substrate ratio, $\mathrm{pH}$, temperature, and time of hydrolysis [11]. Commercial microbial (Alcalase ${ }^{\circledR}$, Protamex $^{\circledR}$, Flavourzyme ${ }^{\circledR}$, and Neutrase ${ }^{\circledR}$ ) or plant (papain, bromelain, actinidain) proteases have been used to hydrolyze beef, chicken, and pig bones, pigskin, and marine fish to produce hydrolysates of increased value [12-16]. For example, hydrolysates of chicken bone extract, made using Protame $x^{\circledR}$ or Flavourzyme ${ }^{\circledR}[14,17]$, and veal bone extract, made using Neutrase ${ }^{\circledR}$ [18], were found to be nutritional and flavorful. This made them potential ingredients as natural meat flavor enhancers for food products including soups and sauces.

To this end, the aim of this study was (i) to produce functional protein hydrolysates from mechanically deboned chicken meat (MDCM) using noncommercial protease enzyme blends (Meatco, the Netherlands), (ii) to gather multidisciplinary information about the properties of the hydrolysates, (iii) to further process the residual bone material to extract collagen with pressurized hot water and optimize the process, (iv) to determine the molecular weight distribution and techno-functional properties of the collagen peptide fractions, and (v) to preliminarily assess the techno-economic feasibility of the developed processes.

\section{Materials and Methods}

\subsection{Chicken MDCM Fractions Enzymatic Processing}

The MDCM was provided by HKScan in Eura in Finland. The byproduct was transported under ice and stored at $-20^{\circ} \mathrm{C}$ to ensure good microbiological quality.

The MDCM fractions were treated with enzymes to separate the soluble and nonsoluble protein, fat, and the residual clean bones. Two different enzyme preparations were used in the studies: (i) Ermitase 1 (ERM 1; endocut in bone treatment) alone, or (ii) ERM 1 in combination with Ermitase 2 (ERM 2; exocut in bone treatment) (Meatco, The Netherlands). Ermitase is a proteolytic enzyme product that contains exclusively endo-proteinase with an activity of $840 \mathrm{UHb} \cdot \mathrm{g}^{-1}$ and is obtained from Bacillus subtilis cultures. The hydrolyses were carried out at $55^{\circ} \mathrm{C}$ with continuous stirring for 60,150 , or $240 \mathrm{~min}$ after the addition of the enzyme. Different solid-liquid ratios (hydromodule $1-3 \mathrm{~L} / \mathrm{kg}$ ) and enzyme-substrate ratios (E:S, $0.05-0.5 \%$ ) were used in the experimental design. The enzyme was inactivated at the end of the processing by heating to $85^{\circ} \mathrm{C}$ and keeping for $15 \mathrm{~min}$. The mixture was then left to rest for $30 \mathrm{~min}$ to separate the non-soluble protein and bone fraction at the bottom of the reactor from the liquid phase containing the soluble protein and the lipids. The lipid fraction was further separated by a separator (Frau CN 3/A, Italy) to obtain high-quality protein while preventing quick deterioration due to the oxidation of the oil. The protein hydrolysate was thereafter dehydrated by freeze-drying until a dry matter content of $>96 \%$ was reached. Figure 1 is a schematic illustration of the processing. 


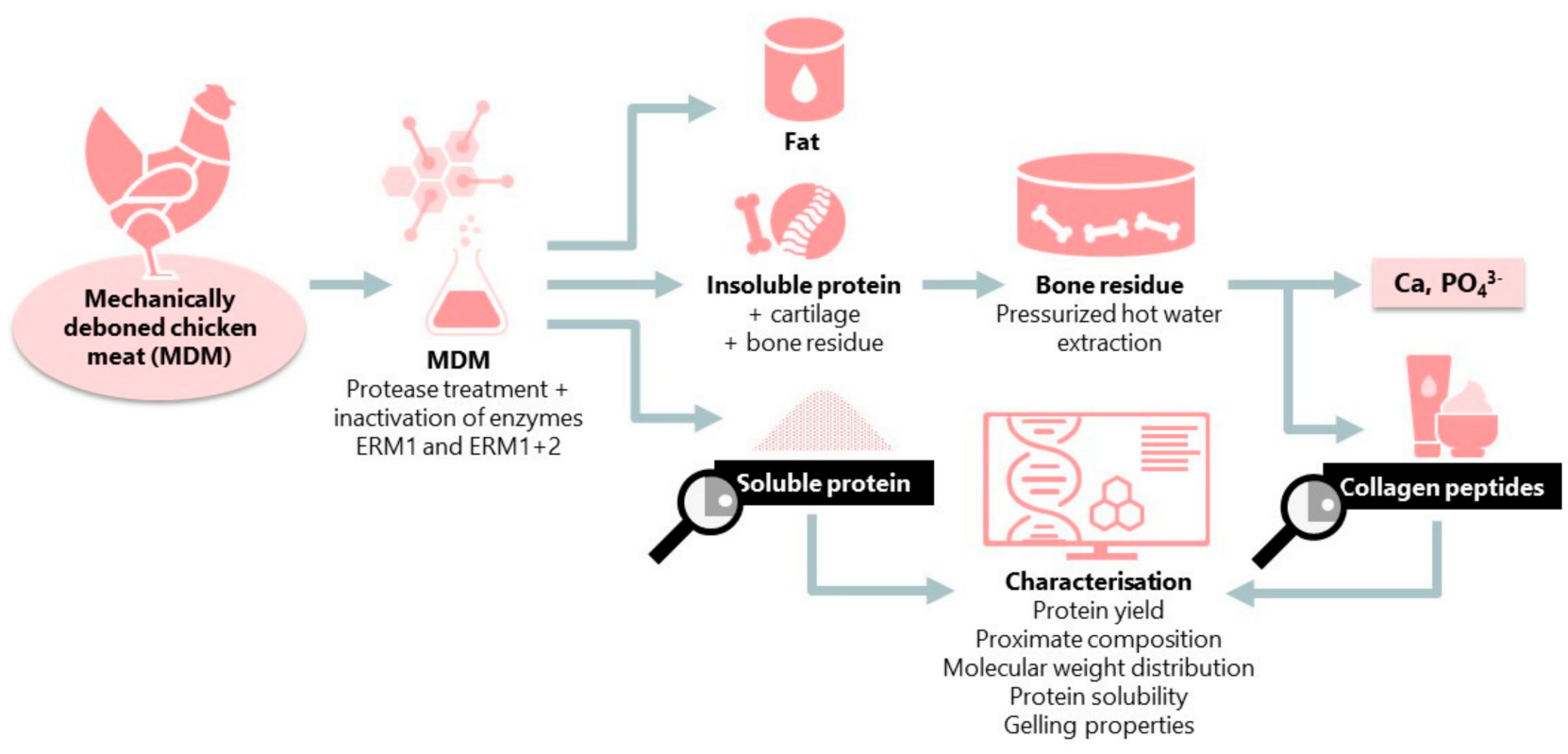

Figure 1. Chicken mechanically deboned meat processing flow chart to produce soluble protein and collagen peptides.

\subsection{Bone Treatment}

To study the bone fraction, $15 \mathrm{~kg}$ of MDCM and $15 \mathrm{~kg}$ of water were mixed constantly with $15 \mathrm{~g}$ of Endocut and $15 \mathrm{~g}$ of Exocut enzymes at $55^{\circ} \mathrm{C}$ for $4 \mathrm{~h}$. The enzymes hydrolyzed the protein from the bone surfaces to generate an almost clean bone fraction. The enzymatically treated bone fractions were separated from the liquid fraction, rinsed clean, and dried in an oven at $58{ }^{\circ} \mathrm{C}$ for about 2 days. The bone yield of the chicken was $45 \%$ (450 g dried bone $/ \mathrm{kg}$ dry second stage MDCM fraction). The dried bones were ground with a hammer mill.

Pressurized hot water extraction (PHWE) was tested to produce and separate collagen peptides. The PHWE treatment was performed in pressure vessels (working volume $30 \mathrm{~mL}$ ). The treatment temperature was controlled with a laboratory oven. The variables for optimizing the conditions were temperature $\left(140-190^{\circ} \mathrm{C}\right)$, treatment time (15-100 min), and dry matter content (5-30\%). To analyze the effect of temperature on the molecular weight of the collagen peptides, a PHWE test series was performed in which the temperature was varied between 110 and $190{ }^{\circ} \mathrm{C}$, and dry matter content (20\%) and treatment time (53 min) were kept constant.

\subsection{Response Surface Methodology (RSF) for Process Optimization}

To identify the optimal process parameters in the enzymatic hydrolyses, Modde 8.1. (Umetrics, Sweden) was used to design the experiments according to CCF design (star distance 1); CCF is composed of a full or fractional factorial design and star points placed on the surfaces of the sides. The design included three factors: hydrolysis time, hydromodule, and E:S ratio. Protein concentration was used as a response function. The design included a total of 17 test runs, with 14 design runs and three center points to validate the model. The experimental design is summarized in Table 1. 
Table 1. CCF design for optimization of MDCM hydrolysis parameters.

\begin{tabular}{|c|c|c|c|c|c|}
\hline \multirow{3}{*}{$\begin{array}{l}\text { Experiment } \\
\text { Number }\end{array}$} & \multicolumn{3}{|l|}{ Factors } & \multicolumn{2}{|c|}{ Response } \\
\hline & Time & $\begin{array}{l}\text { Hydromodule } \\
\text { (L:S) }\end{array}$ & $\mathrm{E}: \mathrm{S}$ & \multicolumn{2}{|c|}{ Protein Yield g/kg } \\
\hline & (h) & $\mathrm{L} / \mathrm{kg}$ & $\%$ & ERM 1 & ERM $1+2$ \\
\hline N1 & 1 & 1 & 0.05 & 60.21 & 72.13 \\
\hline N2 & 4 & 1 & 0.05 & 51.20 & 94.69 \\
\hline N3 & 1 & 3 & 0.05 & 47.90 & 53.04 \\
\hline N4 & 4 & 3 & 0.05 & 45.50 & 66.53 \\
\hline N5 & 1 & 1 & 0.5 & 81.86 & 86.87 \\
\hline N6 & 4 & 1 & 0.5 & 121.12 & 155.24 \\
\hline N7 & 1 & 3 & 0.5 & 50.91 & 74.81 \\
\hline N8 & 4 & 3 & 0.5 & 64.07 & 88.61 \\
\hline N9 & 1 & 2 & 0.275 & 67.62 & 90.09 \\
\hline N10 & 4 & 2 & 0.275 & 70.44 & 80.17 \\
\hline N11 & 2.5 & 1 & 0.275 & 105.79 & 28.64 \\
\hline N12 & 2.5 & 3 & 0.275 & 72.27 & 78.27 \\
\hline N13 & 2.5 & 2 & 0.5 & 58.40 & 77.45 \\
\hline N14 & 2.5 & 2 & 0.5 & 56.95 & 104.37 \\
\hline N15 & 2.5 & 2 & 0.275 & 77.77 & 100.11 \\
\hline N16 & 2.5 & 2 & 0.275 & 70.40 & 101.89 \\
\hline N17 & 2.5 & 2 & 0.275 & 77.78 & 74.48 \\
\hline
\end{tabular}

The protein yield was calculated as follows:

Protein yield (\%)

$=\frac{\text { Protein concentration in the protein hydrolysate }(\%) \times \text { Weight of protein hydrolysate }(\mathrm{g})}{\text { Protein }}$. Protein concentration in the raw material $\times$ Weight of raw material $(\mathrm{g})$

To optimize collagen peptide production, a CCF design was used, and the results were modeled with response surface modelling with Modde 10 (Umetrics, Sweden). The factors were temperature, time, and dry matter content, and the responses were the nitrogen yield of the solution (describes the protein yield) and the mineral content of the solid residue. The design included a total of 20 test runs, with six center points. Table 2 summarizes the design.

The experiments were conducted in random order to avoid systematic error, and the optimal processing parameters were determined using the software's optimizer function. All the experiments were included in the final modeling, as none of the measurements were indicated to be a statistical outlier. New test runs using the determined optimal conditions were performed to verify the model's validity. The soluble protein fraction was analyzed for proximate composition, techno-functional properties, and molecular weight distribution. 
Table 2. CCF design for optimization of bone treatment for collagen peptide production.

\begin{tabular}{|c|c|c|c|c|c|c|}
\hline Exp Name & Run Order & Temperature ${ }^{\circ} \mathrm{C}$ & Dry Matter & Time (min) & Protein Yield (\%) & $\begin{array}{c}\text { Mineral } \\
\text { Concentration }(\mathrm{g} / \mathrm{kg})\end{array}$ \\
\hline N1 & 13 & 140 & 5 & 15 & 33.5 & 69.91 \\
\hline N2 & 15 & 190 & 5 & 15 & 63.75 & 81.12 \\
\hline N3 & 20 & 140 & 30 & 15 & 59.06 & 69.84 \\
\hline N4 & 2 & 190 & 30 & 15 & 73.68 & 79.42 \\
\hline N5 & 16 & 140 & 5 & 100 & 60.82 & 79.2 \\
\hline N6 & 17 & 190 & 5 & 100 & 87.06 & 85.68 \\
\hline N7 & 5 & 140 & 30 & 100 & 76.74 & 77.77 \\
\hline N8 & 9 & 190 & 30 & 100 & 80.59 & 84.32 \\
\hline N9 & 10 & 140 & 17.5 & 57.5 & 66.74 & 77.26 \\
\hline N10 & 12 & 190 & 17.5 & 57.5 & 79.53 & 83.13 \\
\hline N11 & 11 & 165 & 5 & 57.5 & 67.8 & 81.31 \\
\hline N12 & 18 & 165 & 30 & 57.5 & 83.59 & 80.64 \\
\hline N13 & 3 & 165 & 17.5 & 15 & 53.26 & 74.56 \\
\hline N14 & 14 & 165 & 17.5 & 100 & 69.32 & 81.03 \\
\hline N15 & 19 & 165 & 17.5 & 57.5 & 71.65 & 80.76 \\
\hline N16 & 6 & 165 & 17.5 & 57.5 & 66.9 & 81.17 \\
\hline N17 & 7 & 165 & 17.5 & 57.5 & 67.48 & 80.02 \\
\hline N18 & 8 & 165 & 17.5 & 57.5 & 64.76 & 79.94 \\
\hline N19 & 4 & 165 & 17.5 & 57.5 & 70.18 & 79.98 \\
\hline N20 & 1 & 165 & 17.5 & 57.5 & 71.53 & 80.58 \\
\hline
\end{tabular}

\subsection{Proximate Analysis}

Protein, fat, moisture, ash, and carbohydrate content were determined or calculated using the procedures described below.

The moisture content was determined by drying the samples at $105^{\circ} \mathrm{C}$ until a constant final weight was reached. Measurements were taken using a thermogravimetric analyzer (LECO TGA 701, Geleen, The Netherlands).

The nitrogen content of the samples was determined with an in-house Kjeldahl method according to the Association of Official Analytical Chemists (AOAC) method 2001.11, SFS EN ISO 20483:2013 and EN ISO5983-2. A correction factor of 6.25 was used in protein content calculations.

The total fat content of the samples was determined using the SoxCap TM 2047 in combination with the Soxtec TM 2050 extraction system with a preparatory acid hydrolysis step and diethyl ether extraction (Foss A/B, Hillerød, Denmark) according to ISO 6492.

The total carbohydrate (TC) content was calculated with the following formula and expressed as $\mathrm{g} / 100 \mathrm{~g} \mathrm{FW}$ :

$\mathrm{TC}(\%)=100-$ moisture $(\%)-$ protein $(\% \mathrm{FW})-$ crude fat $(\% \mathrm{FW})-\operatorname{ash}(\% \mathrm{FW})$.

The ash content was analyzed by weighing the samples before and after burning at $550{ }^{\circ} \mathrm{C}$ until a constant weight was reached. Measurements were taken with a thermogravimetric analyzer (LECO TGA 701, Geleen The Netherlands). The ash content of the bone fractions was analyzed by weighing the samples before and after burning at $550{ }^{\circ} \mathrm{C}$ for $2 \mathrm{~h}$. 


\subsection{Protein Molecular Weight Distribution Analysis}

Protein hydrolysates produced with PHWE were subjected to size exclusion chromatography to analyze the protein fragmentation during the PHWE treatments. As a first step, the PHWE extracts were purified from non-proteinaceous components with solid-phase extraction using Sep-Pak C18 cartridges. The molecular weight distribution of the purified hydrolysates was then analyzed with a UPLC method, using an Acquity UPLC system (Waters Corporation, USA) equipped with an Acquity BEH125 SEC column, 1.7 um particles, $4.6 \times 150 \mathrm{~mm}$ (Waters Corporation, Milford, MA USA). Proteins and peptides were eluted with $100 \mathrm{mM}$ sodium phosphate buffer $\mathrm{pH} 6.8$ with a flowrate of $0.3 \mathrm{~mL} / \mathrm{min}$.

\subsection{Functional Properties}

The MDCM hydrolysates produced at the optimal processing conditions were tested for their functionality in terms of nitrogen solubility and gelling properties.

Protein solubility was determined using an in-house method. Protein dispersions $(1 \%, w / v)$ were prepared in water; the $\mathrm{pH}$ was adjusted to 8 with $0.5 \mathrm{M}$ or $0.1 \mathrm{M} \mathrm{NaOH}$, and the samples were stirred at room temperature for $2 \mathrm{~h}$. The suspension was divided into two parts: one part was stored at $-20^{\circ} \mathrm{C}$ until further analysis, while the remainder was centrifuged at $3000 \times g$ for $10 \mathrm{~min}$. The supernatants were filtered through a Whatman 42 filter, collected, and stored at $-20^{\circ} \mathrm{C}$ until analysis. The nitrogen content of the suspension and the filtered supernatant was determined using the Kjeldahl protocol described above. The nitrogen solubility index was expressed as

$$
\text { NSI }(\%)=\frac{\text { concentration of nitrogen in supernatant }}{\text { total nitrogen concentration }} \times 100 \text {. }
$$

Gel hardness was measured from protein hydrolysate gels with a protein content of $5 \%$ at $\mathrm{pH} 5.5, \mathrm{pH} 6.0$, and $\mathrm{pH} 6.5$, and a $10 \%$ solution at $\mathrm{pH} 5.5$ was prepared for the gel hardness analysis, and the results were compared between samples. The $\mathrm{pH}$ was adjusted with $0.1 \mathrm{M} \mathrm{HCl}$, the solution was stirred at room temperature with $150 \mathrm{rpm}$ for $1 \mathrm{~h}$, and the $\mathrm{pH}$ was measured and adjusted if required. The solutions were transferred to stirring bottles and filled with MilliQ water to reach a volume of $50 \mathrm{~mL}$, and $1.9 \mathrm{~mL}$ was transferred to $2.5 \mathrm{~mL}$ Eppendorf tubes. One Eppendorf tube was filled with water for temperature control. The tubes were incubated for $45 \mathrm{~min}$ at $80^{\circ} \mathrm{C}$, transferred to an ice bath, and left for $16 \mathrm{~h}$ at $6{ }^{\circ} \mathrm{C}$. The samples were tempered to room temperature for $30 \mathrm{~min}$ before the gel hardness measurement. The hardness was measured with a Lloyd texture analyzer (Lloyd LR, 10K, Worthing UK) with a depression limit of $8 \mathrm{~mm}$ and a trigger of $0.001 \mathrm{kgf}$, and the gel hardness value data were collected.

\subsection{Profitability Assessment for MDCM Sidestream Valorization}

The process diagram for MDCM side-stream valorization (Figure 1) developed in this study was used as the starting point for the profitability assessment. The process yields food-grade chicken protein hydrolysate, chicken bone collagen peptides, chicken fat, and calcium- and phosphate-rich minerals. The assessment was performed for a hypothetical processing plant treating $1.0 \times 10^{7} \mathrm{~kg}$ of chicken MDCM annually.

The values used as the input in calculating the material balance were as follows: dry matter content of the MDCM, 39\%; yield of pure bones after protease treatment, $45 \%$; mineral fraction in chicken bones, $61 \%$; calcium and phosphorus content in the mineral fraction, $80 \%$. Chicken bone proteins account for $70 \%$ of bone organic fraction, and collagen accounts for $90 \%$ of bone protein [19].

\section{Results and Discussion}

\subsection{MDCM Protein Hydrolysate Production}

The volume and protein concentrations of the produced protein fraction were collected, and the protein yield was calculated to establish the statistical model between processing 
factors and the response. The model was fitted with multiple linear regression, and ANOVA was performed. The resulting regression coefficients for MDCM meat hydrolyzed with ERM 1 were as follows: $R^{2}=0.888 ; Q^{2}=0.451$. ANOVA showed that the model was statistically significant $(p=0.001)$, and no lack of fit was observed $(p=0.166)$. Similarly, in the second set of experiments when both ERM 1 and ERM 2 were used in the hydrolyses process, these values were $R^{2}=0.687$ and $\mathrm{Q}^{2}=0.615$. ANOVA showed that the model was statistically significant $(p=0.001)$, and no lack of fit was observed $(p=0.620)$ in this case.

The results indicated that there was a difference in the dominant factors in the ERM 1 and ERM $1+2$ treatments. Hydromodule and the enzyme-substrate ratio as main factors played a significant role in protein recovery with the single ERM 1 enzyme hydrolyses, while the hydrolysis time did not play significant role. The interaction terms were also investigated, and hydrolysis time, the hydromodule, and the enzyme-substrate ratio, therefore, played an important role in the model. Furthermore, the second orders of the hydromodule and the enzyme-to-substrate ratio were also significant in the modeling. On the basis of the results, the second-order polynomial equation to describe the model is as follows:

$$
Y=8.766 X_{1}-27.90 X_{2}+22.34 X_{3}+23.41 X_{2}^{2}-39.29 X_{3}^{2}+15.99 X_{1} X_{2}-15.95 X_{2} X_{3},
$$

where $\mathrm{Y}(\%)$ is protein recovery, $\mathrm{X}_{1}=$ time, $\mathrm{X}_{2}=$ hydromodule $(\mathrm{L} / \mathrm{kg})$, and $\mathrm{X}_{3}=\mathrm{E}: \mathrm{S}$ ratio.

In the optimization function, a hydrolysis time of $4 \mathrm{~h}$, an E:S ratio of $0.4325 \%$, and a hydromodule of $1 \mathrm{~L} / \mathrm{kg}$ were selected. In these conditions, protein recovery was shown to be above $114.03 \mathrm{~g} / \mathrm{kg}$ protein stock (yield of approximately 90\%) with ERM 1 .

The model was shown to be simpler in the case of hydrolyses with both ERM 1 and ERM 2, in which case only the major terms, the time of the hydrolyses, the hydromodule, and the enzyme-substrate ratio, played a significant role in the protein recovery, although the model fitting showed lower $R^{2}$ and $\mathrm{Q}^{2}$ values than those described above.

The second-order polynomial equation based on the results to describe the model is as follows:

$$
Y=21.66 X_{1}-35.62 X_{2}+21.66 X_{3} .
$$

In the optimization function, a hydrolysis time of $4 \mathrm{~h}$, an E:S ratio $0.2709 \%$ for both enzymes, and a hydromodule of $1 \mathrm{~L} / \mathrm{kg}$ were selected. In these conditions, the protein concentration was above $118.03 \mathrm{~g} / \mathrm{kg}$ protein stock (yield of approximately $90 \%$ ) with ERM $1+2$ enzymes. The longer enzymatic treatment $(72 \mathrm{~h})$ of MDCM was found also more favorable to achieve higher hydrolysate yield $(6.2-6.8 \%)$; correspondingly, the total gelatin recovery was also significantly influenced by the extraction temperature and time with close to a final recovery yield of $46 \%$. Lindberg et al. [20], on the other hand, determine that the optimal combination of different proteases might be a good way toward more profitable processing with an increase in yield of $15 \%$ in poultry byproduct valorization, making the process even more profitable. The model was verified by repeating the experiments twice within the optimal process parameters, and similar results were found for the protein concentration and recovery values.

Table 3 shows the proximate composition of fractions produced in optimal conditions after $4 \mathrm{~h}$ of hydrolysis with one enzyme and the combination of enzymes using the optimal process conditions. Lindberg et al. [20] also found that the recovery yield was higher when the time of hydrolyses was increased from $1 \mathrm{~h}$ to $3 \mathrm{~h}$; however, little improvement in recovery was observed beyond the $3 \mathrm{~h}$ time. There were no considerable differences in protein concentrations between the hydrolysate fractions prepared with ERM1 or ERM $1+2$, and ERM 1 alone was effective. The fat concentrations showed more differences between treatments that might be due to an incomplete separation in the $4 \mathrm{~h}$ ERM $1+2$ treatments rather than analytical error. 
Table 3. The ash, dry matter, protein, and fat content of the soluble protein fraction after treatment with ERM 1 and ERM $1+2$ for $4 \mathrm{~h}$.

\begin{tabular}{ccccccc}
\hline Enzyme & Time of Hydrolysis & Ash (\% DW) & Dry Matter & Protein (\% DW) & Fat (\% DW) \\
\hline Ermitase 1 & $4 \mathrm{~h}$ & 9.90 & 93.31 & 87.01 & 0.74 \\
\hline Ermitase $1+2$ & $4 \mathrm{~h}$ & 11.58 & 95.16 & 86.17 & 2.44 \\
\hline
\end{tabular}

The protein yield depends on the extraction method, raw material type, and the deboning machine [21]. Studies have shown that, depending on the extraction method, $6.7-17.6 \%$ of total protein from chicken bone may be recovered. Kijowski and Ntewtarowicz [21] extracted chicken bone with a water solution of $\mathrm{NaCl}$ with the addition of $\mathrm{NaNO}_{2}$ and ascorbate, and they obtained extracts containing $3.4 \%$ of protein, which constituted $18 \%$ of total chicken bone protein. Young [22] reported a yield of $11-17 \%$ from total protein content in animal bone, while Lawrence and Jelen [23] reported that more than $18 \%$ of the protein in chicken bone was alkali-extractable. Dong et al. [14] observed that $80.25 \%$ of the protein in the chicken bone could be extracted using the hot-pressure extraction method. Papain was used for enzymatic hydrolysis for its highest protein extraction rate (46\%) of chicken bone protein compared to other enzymes (trypsin $44 \%$, protamex $40 \%$, alkaline protease $35 \%$, neutral protease $32 \%$, pepsin $28 \%$, flavored proteinase $19 \%$ ). Additionally, ultrasonic treatment was shown to gradually increase the protein yield as the processing temperature increased, reaching the highest yield $(56.49 \% \pm 0.67 \%)$ at $45^{\circ} \mathrm{C}$ [24]. In a recent study, Lindberg et al. [25] investigated the impact of three commercial proteases, Alcalase 2.4 L, Corolase 2TS, and Flavourzyme, on the quality of chicken and turkey carcasses and MDCM. The results showed that the choice of protease and industrially relevant variations in poultry raw material composition both had a major effect on product composition and protein yield, nutrient and amino-acid composition, degree of hydrolysis, size distribution of peptides, and rheological properties. Alcalase was the most efficient protease, while Flavourzyme hydrolysis resulted in substantially lower nitrogen yields [25]. According to the present study's findings, around $87 \%$ of the proteins from the chicken MDCM were extracted with the Ermitase enzymes, indicating their superiority to other enzymes.

\subsection{Properties of Extracted Protein Hydrolysates}

Enzymatic hydrolysis treatments in the optimal process conditions produced protein fragments with a broad molecular weight range. The smallest fragments were observed at a molecular weight of $50 \mathrm{Da}$, and the largest proteins were observed at $45 \mathrm{kDa}$. The majority (approximately $70 \%$ ) of the proteins were around $10 \mathrm{kDa}$, indicating that the hydrolysis treatments were rather mild.

The nitrogen solubility index (NSI\%), which describes the proportion of nitrogen that is water-soluble compared with total nitrogen content, is relevant to the evaluation of protein quality. The NSI values of the hydrolyzed chicken MDCM protein fractions were determined at $\mathrm{pH} 5-8$ and are shown in Figure 2. 


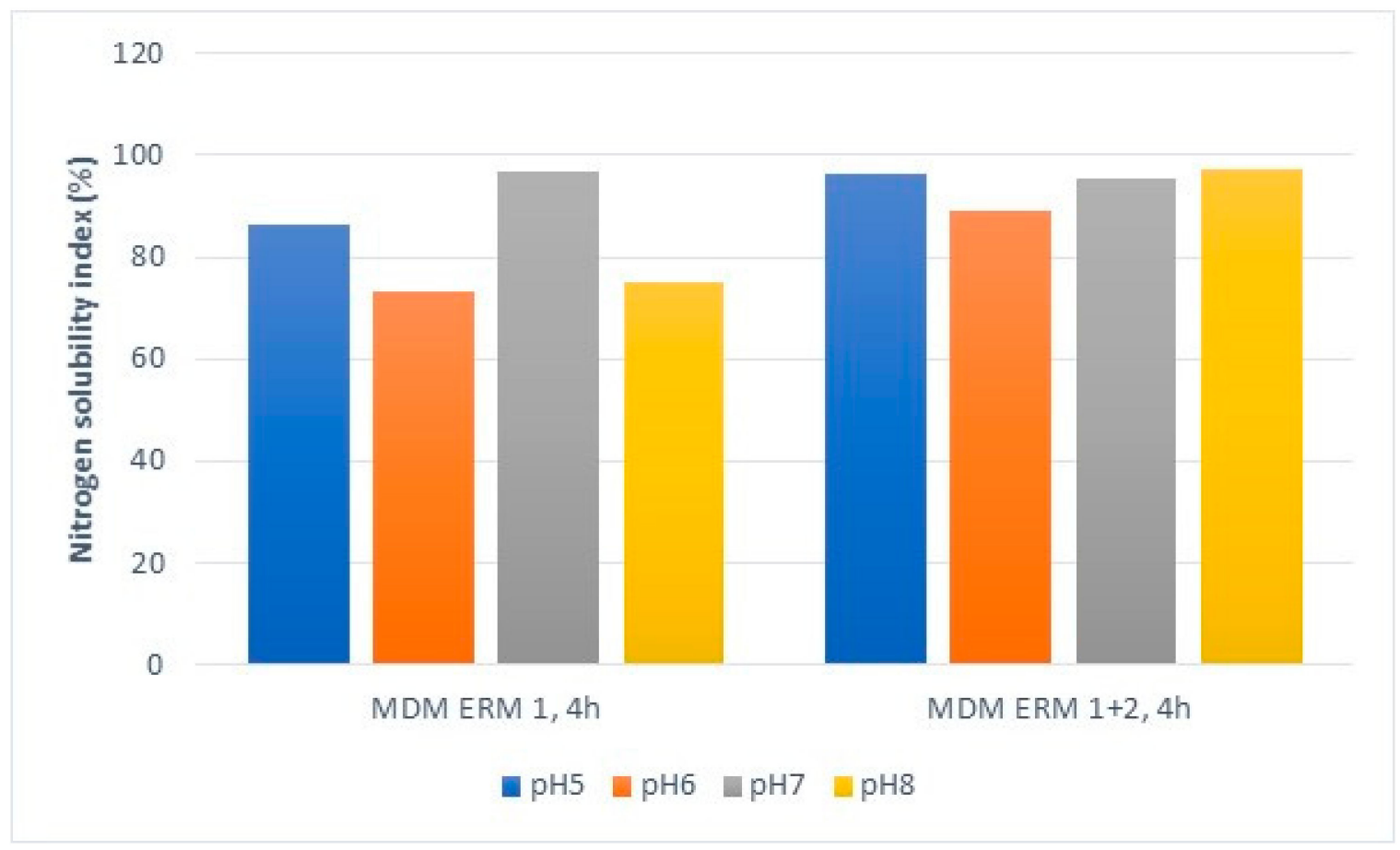

Figure 2. Nitrogen solubility index of chicken MDCM protein fractions obtained with ERM1 or ERM1 + 2 after $4 \mathrm{~h}$ hydrolysis.

The measurements indicated that a large proportion of the samples had a high solubility of up to $90 \%$, and no clear trend in the $\mathrm{pH}$ change was observed. Using ERM 1 and 2 enzymes increased solubility at $\mathrm{pH} 6$. The protein fraction from MDCM seemed to have much lower solubility at $\mathrm{pH} 6$ after four hydrolyses when the hydrolysis was carried out only using ERM 1, but the solubility increased remarkably when both ERM 1 and ERM 2 were used.

The gelling property and gel hardness were evaluated at concentrations of $5 \%, 10 \%$, and $15 \%$ and at $\mathrm{pH}$ values of $\mathrm{pH} 6.0$ and $\mathrm{pH}$ 6.5. Furthermore, gelatin gels made by adjusting the protein content to $6.67 \%$ were used as a reference. Gel hardness was measured with a Lloyd's instrument (Lloyd LR 10K, Geleen UK). The results showed that gels from MDCM fractions were remarkably weaker than the reference gelatin. It was also revealed that there was no major difference in gel hardness whether ERM 1 or ERM $1+2$ enzymes were used in the hydrolysis. At pH 6.0 and 5\% protein content, the ERM 1 gel hardness was $0.0145 \pm 0.01 \mathrm{~N}$, and the ERM $1+2$ showed a hardness of $0.01 \pm 0.0061 \mathrm{~N}$. The effect of the $\mathrm{pH}$ on gel hardness was somewhat more visible in the results. The gel with $10 \%$ protein content treated in ERM 1 treatment showed a gel hardness of $0.014 \pm 0.0022 \mathrm{~N}$ at $\mathrm{pH} 5.5$. At $\mathrm{pH}$ 6, the value was $0.036 \pm 0.016 \mathrm{~N}$. To this end, a considerable difference in hardness was observed at the same $10 \%$ protein content but different $\mathrm{pH}$ in ERM 1 treatment; at $\mathrm{pH}$ 6, the gel had 20 times higher hardness compared to $\mathrm{pH}$ 5.5.

The gel hardness of protein fraction is an important factor to determine its applicability in foods. In many meat-related products, the gelling property is important to obtain the proper structure and functionality. If the protein derived from the mechanically deboned meat through enzymatic hydrolyses has no good gelling property, the amount added to the product should be carefully calculated to avoid having a negative impact on the final hardness, chewiness, and taste of the product. For example, Cavalheiro et al. [26] observed that up to $10 \%$ of chicken meat could be replaced with MDCM hydrolysates with an effect on the organoleptic and physicochemical properties of Mortadella-type sausage.

It is also important to mention that this study's aim was not to produce a protein isolate but to develop a simple and affordable technology for the better valorization of mechanically deboned meat. 


\subsection{Residual Bone Treatment}

\subsubsection{Treatments and Optimization Parameters}

According to preliminary experiments, pressurized hot water extraction proved the most promising way to separate collagen peptides. The variables in optimizing the conditions were temperature $\left(140-190^{\circ} \mathrm{C}\right)$, treatment time (15-100 min), and dry matter content (5-30\%). The responses were the nitrogen yield of the solution (describes protein yield) and the mineral content of the solid residue. A statistical test design (CCF) was used in the series of experiments, and the results were modeled by response surface modeling. Good, reproducible, and predictive models were obtained for both responses. The nitrogen yield indices were $R^{2}=0.96, \mathrm{Q}^{2}=0.86$, validity $=0.77$, and reproducibility $=0.94$. Correspondingly, $R^{2}=0.98, Q^{2}=0.96$, validity $=0.68$, and reproducibility $=0.98$ were obtained for the mineral content. The results show that a high temperature and long exposure time significantly improved the yield (Figure 3).
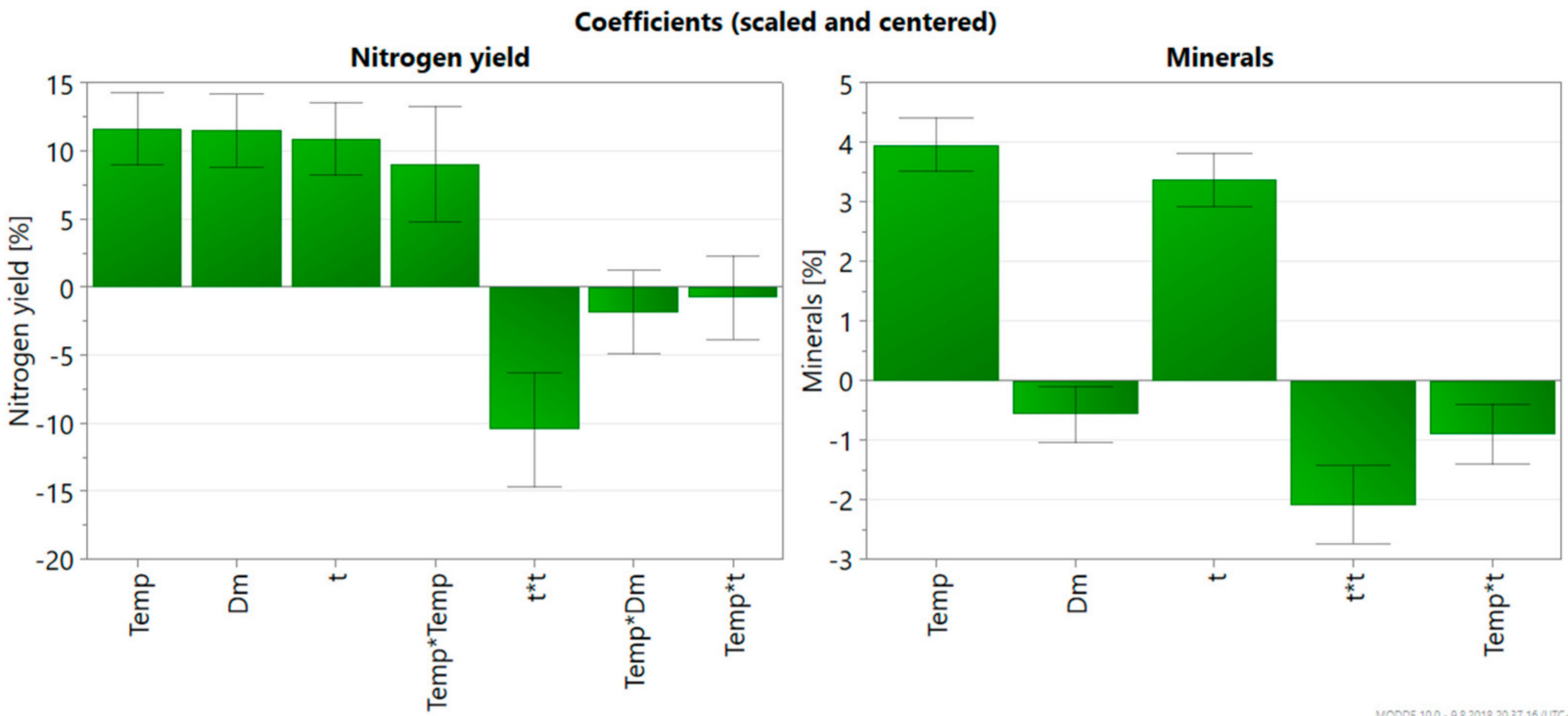

Figure 3. Factors affecting nitrogen and mineral yield in the processing of chicken MDCM clean bones.

The equation to describe the model in the case of collagen yield is

$$
\begin{gathered}
\text { Nitrogen yield }=8.78 \mathrm{X}_{1}+6.07 \mathrm{X}_{2}+9.13 \mathrm{X}_{3}+5.73 \mathrm{X}_{2}^{2}-8.68 \mathrm{X}_{3}{ }^{2}-4.75 \mathrm{X}_{1} \mathrm{X}_{2}- \\
1.85 \mathrm{X}_{1} \mathrm{X}_{2}-3.26 \mathrm{X}_{2} \mathrm{X}_{3}+69.87,
\end{gathered}
$$

where $X_{1}=$ temperature, $X_{2}=$ dry matter $(\%)$, and $X_{3}=$ treatment time ( $\left.\mathrm{min}\right)$. The equation to describe the model in the case of mineral content is

$$
\text { Mineral content }=3.97 \mathrm{X}_{1}-0.52 \mathrm{X}_{2}+3.32 \mathrm{X}_{3}+0.62 \mathrm{X}_{2}^{2}-2.56 \mathrm{X}_{3}^{2}-0.97 \mathrm{X}_{1} \mathrm{X}_{3}+
$$

The values of the optimal point variables predicted by the model were $190^{\circ} \mathrm{C}, 83 \mathrm{~min}$, and $5 \%$ dry matter content. The model predicted a nitrogen yield of $86 \%$ for the extract and a mineral content of $86 \%$ for the remaining bone fraction. The model was validated by performing an extraction experiment in optimal conditions. The measured nitrogen yield was $86.9 \% \pm 2.3 \%$, and the mineral content was $84.5 \% \pm 0.2 \%$. The measured values were very close to the values predicted by the model; thus, the modeling was successful. In addition, the yields were high; as such, PHWE appears to be a promising method for isolating collagen peptides from chicken bones. In the second test series, PHWE treatment was performed with constant dry matter content (20\%) and extraction time (53 $\mathrm{min})$, and the temperature was varied $\left(110-190{ }^{\circ} \mathrm{C}\right)$. 
The samples were analyzed for nitrogen content and mineral content. The results confirmed the observation of a previous series of experiments that raising the temperature increased the yield of collagen peptides (Figure 4). The purpose of this series of experiments was to further investigate the peptide composition of the extracted fractions and the effect of temperature on the composition.
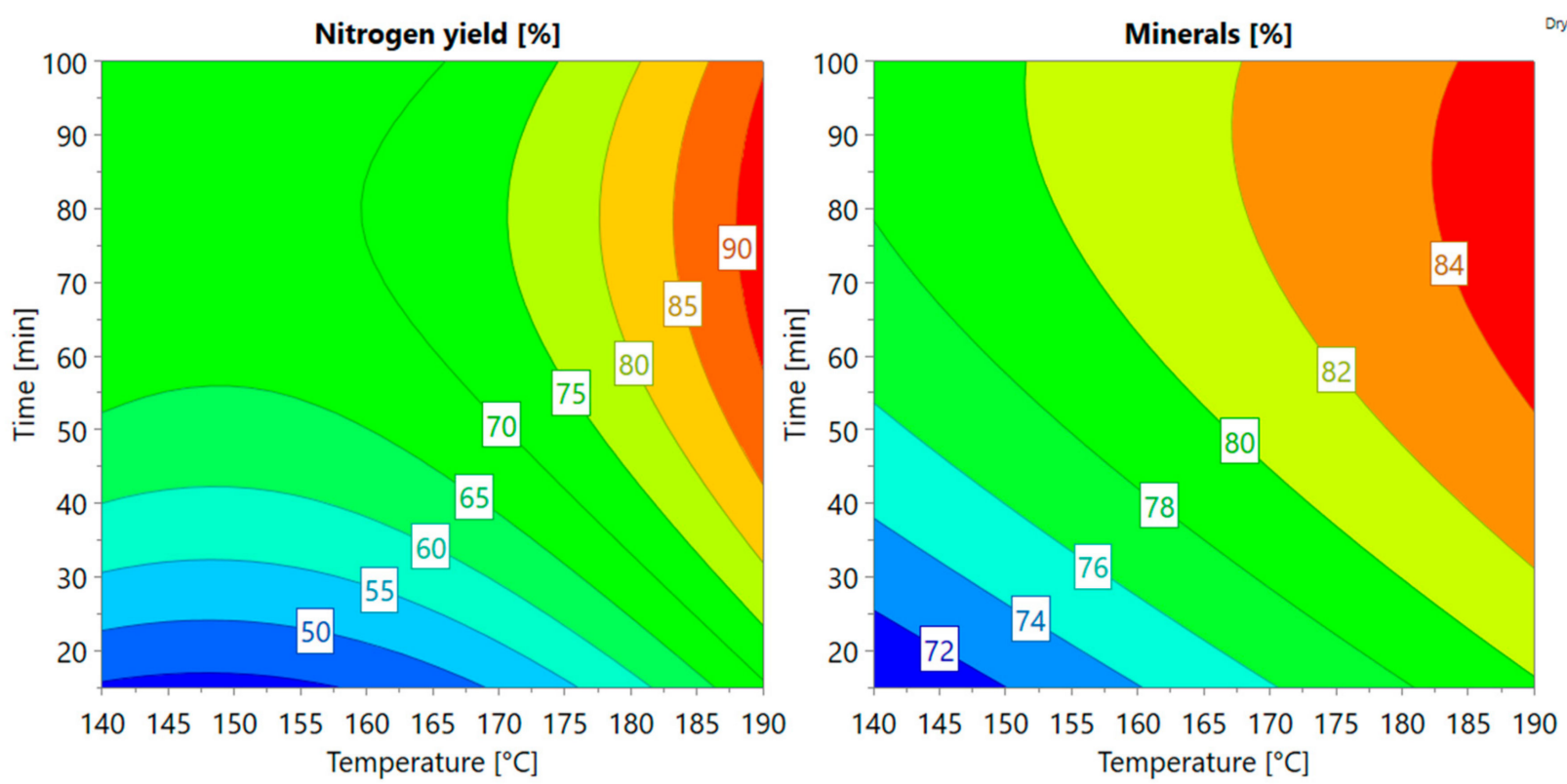

Figure 4. The response surface of the enzymatic hydrolysis model of MDCM clean bones showing the relationships between nitrogen and mineral yield, temperature, and hydrolysis time.

\subsubsection{Molecular Weight Distribution and Peptide Profiles}

The molecular size distribution was determined from the residual bone PHWE extracts to assess the effect of temperature on collagen cleavage. According to the results of size exclusion chromatography, the majority of the proteinaceous compounds in the PHW extracts of chicken bones were in the range of 0.5-13.7 kDa in MW with all extraction temperatures applied (Figure 5). The proportion of MW range of 0.5-13.7 kDa compounds varied from $61 \%\left(110^{\circ} \mathrm{C}\right)$ to $75 \%\left(190^{\circ} \mathrm{C}\right)$ between the applied temperatures. The results showed that an increase in the extraction temperature resulted in increased protein fragmentation. In particular, the proportion of proteins with MW higher than $44.2 \mathrm{kDa}$ was reduced by increasing the extraction temperature. At an extraction temperature of $190{ }^{\circ} \mathrm{C}$, the degradation products were the smallest; the proportion of compounds with MW smaller than $0.5 \mathrm{kDa}$ was higher in comparison to the extracts produced at the lower temperatures. This indicates that the free amino acids and di- and tripeptides were more abundant in the PHW extract produced at $190{ }^{\circ} \mathrm{C}$ than in extracts produced at lower temperatures. 


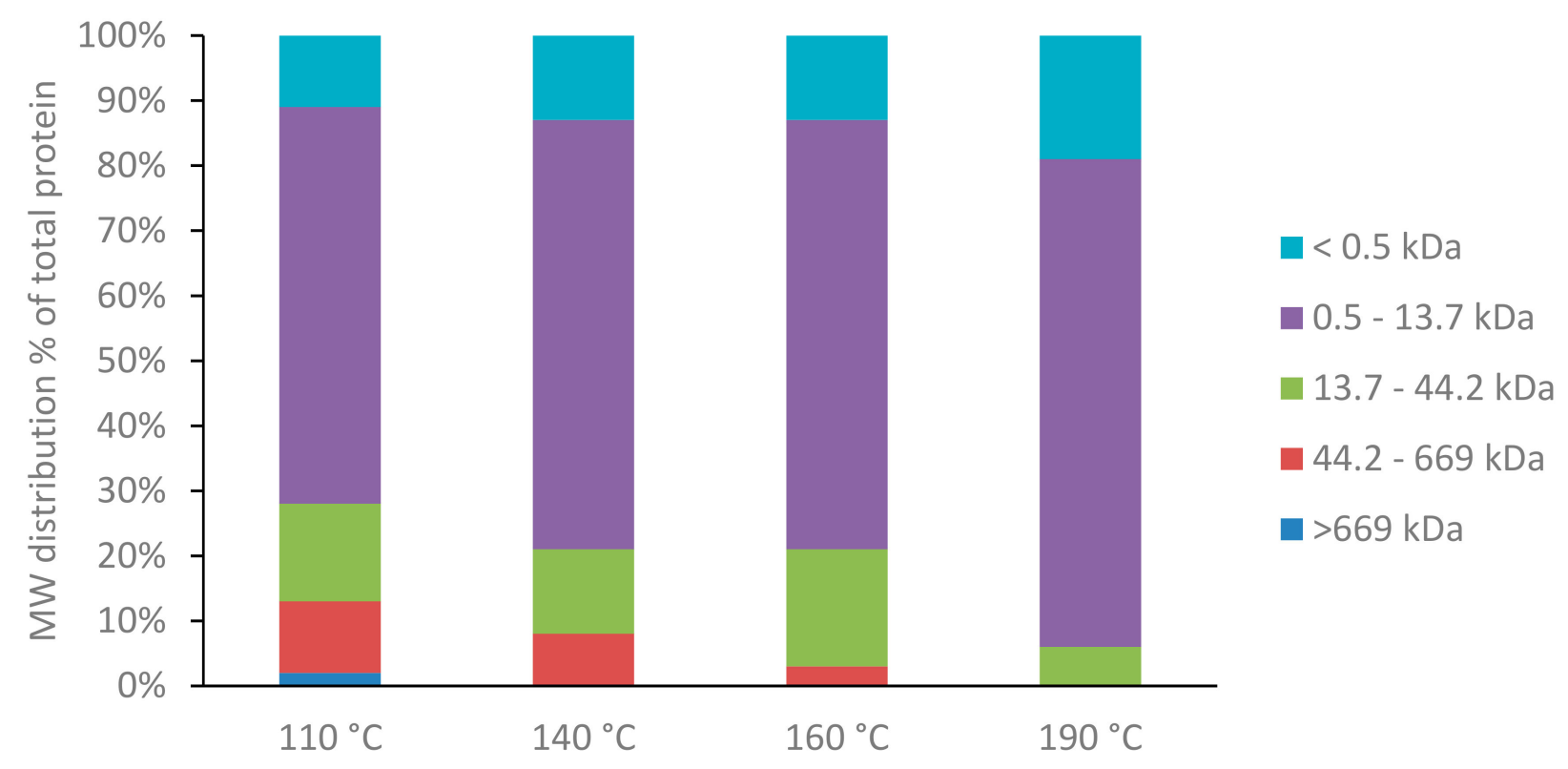

Figure 5. Molecular weight distribution of the proteinaceous compounds in chicken bone PHW extracts.

The skin is the largest organ of the human body and acts as a barrier that protects us against various external damages. It is also an important organ, regulating temperature and fluid-electrolyte balance and metabolism, for example [27]. Collagen and its hydrolysates have attracted particular attention because of their skin-enhancing properties. Cosmetic and edible cosmetic formulations use hydrolyzed collagen for its superior solubility at a neutral $\mathrm{pH}$, its easy dermis penetration, and its water-binding properties [28]. Recently, many studies have reported skin antiaging and healthcare properties in small collagen peptides [29]. Chicken bones, as sustainable residual materials, have received special attention as a source of collagen (reviewed by Salvatore et al. [30]).

The present study shows that PHWE treatment is a promising method for producing collagen peptides with a low molecular weight from chicken bones, a sustainable residual material from food processing. The nitrogen yield from the purified bones was high (87\%), indicating that most of the chicken bone protein was extracted. The results are in line with the findings of Wang et al. [31], who studied PHWE treatment with chicken bones at $120-135{ }^{\circ} \mathrm{C}$. They also found that increasing the treatment temperature improved the recovery of collagen. In addition to PHWE treatment, other extraction methods have been studied to recover collagen from chicken bones; attempts have been made with an $\mathrm{NaCl}$ solution containing small amounts of $\mathrm{NaNO}_{2}$, ascorbate, and $\mathrm{Na}_{4} \mathrm{P}_{2} \mathrm{O}_{7}$, combined with homogenization [21] and alkali extraction [32]. Chicken foot collagen extraction has been reported with papain and pepsin enzymes in an acetic acid solution [33] and with dilute acid treatment [34]. Moreover, extraction studies of turkey bones have been performed with dilute alkaline $\mathrm{NaCl}$ solutions [35] and acid and alkaline treatment [36]. These methods have yielded $46 \%$ collagen peptides at best. It can, therefore, be stated that, among the methods studied so far, PHWE seems the most efficient way of extracting chicken collagen peptides.

In this study, the smallest collagen peptides were produced at temperatures above $150{ }^{\circ} \mathrm{C}$. However, a large proportion of the total protein in the bone extracts was small peptides below $10 \mathrm{kDa}$ already at a rather mild temperature between 110 and $140{ }^{\circ} \mathrm{C}$. The results indicate the suitability of the chicken bone PHW extracts for cosmetic use, but more research is needed to investigate the skin enhancing effects on the cellular level and in vivo. 


\subsection{Profitability Assessment}

The assessment was performed for a hypothetical fractionation process plant, treating $1.0 \times 10^{7} \mathrm{~kg}$ of chicken MDCM side-stream annually, and yielding food-grade chicken protein hydrolysate, chicken bone collagen peptides, chicken fat, and calcium- and phosphaterich minerals. The theoretical annual amounts of these products from $1.0 \times 10^{7} \mathrm{~kg}$ of chicken MDCM were calculated on the basis of the values given in Section 2.7. A total yield of fractionation processing estimated as $80 \%$ was used to calculate the amounts of products obtained.

The annual production, prices, and revenues of the chicken MDCM side products are presented in Table 4 . The applied prices were based on expert and industry knowledge. According to the assessment, the total sales revenues for the side products were about $5.5 \times 10^{6} \mathrm{EUR} /$ year. Of this, $62 \%$ were derived from collagen peptides, and $31 \%$ were derived from MDCM protein hydrolysate.

Table 4. Annual production and sales revenues of different chicken MDCM side products.

\begin{tabular}{cccc}
\hline Product & Production, $\mathbf{1 0}^{\mathbf{6}} \mathbf{~ k g / \text { year }}$ & Price, EUR/kg & Revenue, $\mathbf{1 0}^{\mathbf{6}}$ EUR/year \\
\hline Collagen peptides (d.w.) & 0.34 & 10.00 & 3.4 \\
\hline MDCM protein hydrolysate (d.w.) & 1.44 & 1.20 & 1.7 \\
\hline $\begin{array}{c}\text { Calcium- and phosphate-rich } \\
\text { mineral fraction }\end{array}$ & 0.69 & 0.18 & 0.12 \\
\hline Chicken fat & 0.27 & 0.85 & 0.23 \\
\hline Total & & & 5.5 \\
\hline
\end{tabular}

The main process equipment consisted of a high-pressure extraction unit, filters, centrifuges, dryers, and a packaging unit. The investment cost depended on the existing utilities and production facilities. If the process was integrated with a chicken slaughterhouse, the investment costs for the MDCM side-stream process were estimated at $1.0 \times 10^{7}$ EUR, according to expert knowledge.

The operating costs included materials, e.g., food grade protease enzymes, operators' salary costs, energy consumption, maintenance and repairs, and other variable costs. Operating costs were estimated at $2.0 \times 10^{6} \mathrm{EUR} /$ year, and the depreciation of investment and rate of interest were estimated at $2.0 \times 10^{6} \mathrm{EUR} /$ year for 10 years. Therefore, the estimated total annual production costs were $4.0 \times 10^{6} \mathrm{EUR}$. The chicken MDCM fractionation process was profitable according to this preliminary assessment; the annual profit was about $1.5 \times 10^{6}$ EUR. This value is in the same range as the profit values calculated for annual processing of $1.0 \times 10^{7} \mathrm{~kg}$ of salmon filleting side-streams to various high-value products [37].

Since prices are the main driver in the protein business case, the price stability is essential. The price of chicken collagen peptides has decreased in recent years, bringing uncertainties concerning the process's profitability. The investment is, therefore, classified as high-risk. The economic feasibility of the process also depends on how well the additional processes fit the existing process, and how well the resulting products can be marketed. The feasibility of a process is always a case-by-case issue, because the skills of the process designer, marketer, and buyer are essential.

\section{Conclusions}

Our study highlighted the use of response surface methodology to optimize parameters for mechanically deboned chicken enzymatic and PHWE treatments to achieve high protein and low-molecular-weight collagen peptide yields. A hydrolysis of $240 \mathrm{~min}$ using noncommercial protease enzyme resulted in high protein concentration and protein hydrolysates with a good solubility index, but weak gelling properties were produced. PHWE treatment at $190^{\circ} \mathrm{C}$ for $83 \mathrm{~min}$ resulted in high nitrogen yield and a fraction with 
high content of peptides lower than $13.7 \mathrm{kDa}$. The results suggest that the profitability of process should be carefully evaluated, due to uncertainties of the price of proteins and collagen peptides.

Author Contributions: Data curation, M.V., J.M., M.K.; Investigation, N.P., S.M., U.M., A.P.; Methodology, N.P., S.M., U.M., M.V., J.M., M.K. Project administration, M.K., A.P.; Supervision, A.P.; Writingoriginal draft, A.P.; Writing-review \& editing, A.P., S.M., N.P., U.M., M.V., M.K., J.M. All authors have read and agreed to the published version of the manuscript.

Funding: This research was funded by Business Finland grant number [899/31/2015].

Institutional Review Board Statement: This study was condacted in accordance to the principles of good scientific practice of the Research Ethics Advisory Board (TENK). It is the responsibility of every researcher to follow good scientific practice.

Informed Consent Statement: Not applicable.

Data Availability Statement: Data ise arranged according to FAIR principles and is available upon request. When opening databases, we shall take into consideration commercial utilisation of the material and results, as well as the protection of the rights.

Acknowledgments: This study was funded by Business Finland. HKScan is greatly acknowledged for funding and providing MDCM for this research. The authors thank Antti Järveläinen for helping with the enzymatic processing of the chicken MDCM fractions and Sara Kujansuu for helping with the PHWE studies.

Conflicts of Interest: All authors claim that there are no conflicts of interest in this study.

\section{References}

1. Lasekan, A.; Bakar, F.A.; Hashim, D. Potential of chicken by-products as sources of useful biological resources. Waste Manag. 2013, 33, 552-565. [CrossRef] [PubMed]

2. Jamdar, S.N.; Harikumar, P. Autolytic degradation of chicken intestinal proteins. Bioresour. Technol. 2005, 96, 1276-1284. [CrossRef] [PubMed]

3. Grazziotin, A.; Pimentel, F.A.; Sangali, S.; de Jong, E.V.; Brandelli, A. Production of feather protein hydrolysate by keratinolytic bacterium Vibrio sp. kr2. Bioresour. Technol. 2007, 98, 3172-3175. [CrossRef] [PubMed]

4. Silvipriya, K.S.; Kumar, K.K.; Bhat, A.R.; Kumar, B.D.; John, A.; Lakshmanan, P. Collagen: Animal sources and biomedical application. J. Appl. Pharm. Sci. 2015, 5, 123-127. [CrossRef]

5. Losso, J.N.; Ogawa, M. Thermal stability of chicken keel bone collagen. J. Food Biochem. 2014, 38, 345-351. [CrossRef]

6. Song, D.H.; Choi, J.H.; Choi, Y.S.; Kim, H.W.; Hwang, K.E.; Kim, Y.J.; Ham, Y.K.; Kim, C.J. Effects of mechanically deboned chicken meat (MDCM) and collagen on the quality characteristics of semi-dried chicken jerky. Korean J. Food Sci. Anim. Resour. 2014, 34, 727-735. [CrossRef]

7. Ockerman, H.W.; Hansen, C.L. Edible Tissue from Bone: Animal by-Product Processing \& Utilization, 1st ed.; CRC Press: Boca Raton, FL, USA, 2000; pp. 217-246.

8. Chen, X.; Liang, L.; Xu, X. Advances in converting of meat protein into functional ingredient via engineering modification of high pressure homogenization. Trends Food Sci. Technol. 2020, 106, 12-29. [CrossRef]

9. Wang, L.; Liang, Q.; Chen, T.; Wang, Z.; Xu, J.; Ma, H. Characterization of collagen from the skin of Amur sturgeon (Acipenser schrenckii). Food Hydrocolloid 2014, 38, 104-109. [CrossRef]

10. Mokrejš, P.; Gál, R.; Pavlaková, J.; Janáová, D. Valorization of a by-Product from the production of mechanically deboned chicken meat for preparation of gelatins. Molecules 2021, 26, 349. [CrossRef]

11. Villamil, O.; Váquiro, H.; Solanilla, J.F. Fish viscera protein hydrolysates: Production, potential applications and functional and bioactive properties. Food Chem. 2017, 224, 160-171. [CrossRef]

12. Hou, H.; Li, B.; Zhao, X.; Zhang, Z.; Li, P. Optimization of enzymatic hydrolysis of Alaska pollock frame for preparing protein hydrolysates with low-bitterness. LWT Food Sci. Technol. 2011, 44, 421-428. [CrossRef]

13. Pagán, J.; Ibarz, A.; Falguera, V.; Benítez, R. Enzymatic hydrolysis kinetics and nitrogen recovery in the protein hydrolysate production from pig bones. J. Food Eng. 2013, 119, 655-659. [CrossRef]

14. Dong, X.B.; Li, X.; Zhang, C.H.; Wang, J.Z.; Tang, C.H.; Sun, H.M.; Jia, W.; Li, Y.; Chen, L.L. Development of a novel method for hot-pressure extraction of protein from chicken bone and the effect of enzymatic hydrolysis on the extracts. Food Chem. 2014, 157, 339-346. [CrossRef] [PubMed]

15. Song, S.; Li, S.; Fan, L.; Hayat, K.; Xiao, Z.; Chen, L.; Tang, Q. A novel method for beef bone protein extraction by lipasepretreatment and its application in the Maillard reaction. Food Chem. 2016, 208, 81-88. [CrossRef] 
16. Chiang, J.H.; Loveday, S.M.; Hardacre, A.K.; Parker, M.E. Effects of enzymatic hydrolysis treatments on the physicochemical properties of beef bone extract using endo- and exoproteases. Int. J. Food Sci. Technol. 2019, 54, 111-120. [CrossRef]

17. Sun, H.M.; Wang, J.Z.; Zhang, C.H.; Li, X.; Xu, X.; Dong, X.B.; Hu, L.; Li, C.H. Changes of flavor compounds of hydrolyzed chicken bone extracts during Maillard reaction. J. Food Sci. 2014, 79, C2415-C2426. [CrossRef]

18. Linder, M.; Rozan, P.; El Kossori, R.L.; Fanni, J.; Villaume, C.; Mejean, L.; Parmentier, M. Nutritional value of veal bone hydrolysate. J. Food Sci. 1997, 62, 183-189. [CrossRef]

19. Cansu, Ü.; Boran, G. Optimization of a multi-step procedure for isolation of chicken bone collagen. Korean J. Food Sci. Anim. Resour. 2015, 35, 431-440. [CrossRef]

20. Lindberg, D.; Kristoffersen, K.A.; Wubshet, S.G.; Hunnes, L.M.G.; Dalsnes, M.; Dankel, K.R.; Høst, V.; Afseth, N.K. Exploring effects of protease choice and protease combinations in enzymatic protein hydrolysis of poultry by-products. Molecules 2021, 26, 5280. [CrossRef]

21. Kijowski, J.; Niewiarowicz, A. A method of protein extraction from chicken bone residue and the chemical and electrophoretic characteristics of the extract. Int. J. Food Sci. Technol. 1985, 20, 43-49. [CrossRef]

22. Young, L.L. Composition and properties of an animal protein isolate prepared from bone residue. J. Food Sci. 1976, 41, 606-608. [CrossRef]

23. Lawrence, R.A.; Jelen, P. Formation of lysino-alanine in alkaline extracts of chicken protein. J. Food Prot. 1982, 45, 923-924. [CrossRef] [PubMed]

24. Dong, Z.Y.; Li, M.Y.; Tian, G.; Zhang, T.H.; Ren, H.; Quek, S.Y. Effects of ultrasonic pretreatment on the structure and functionality of chicken bone protein prepared by enzymatic method. Food Chem. 2019, 299, 125103. [CrossRef] [PubMed]

25. Lindberg, D.; Kristoffersen, K.A.; de Vogel-van den Bosch, H.; Wubshet, S.G.; Böcker, U.; Rieder, A.; Fricke, E.; Afseth, N.K. Effects of poultry raw material variation and choice of protease on protein hydrolysate quality. Process Biochem. 2021, 110, 85-93. [CrossRef]

26. Cavalheiro, C.P.; Lüdtke, F.L.; Stefanello, F.S.; Kubota, E.H.; Terra, N.N.; Fries, L.L.M. Replacement of mechanically deboned chicken meat with its protein hydrolysate in mortadella-type sausages. Food Sci. Technol. 2014, 34, 478-484. [CrossRef]

27. Zouboulis, C.C.; Makrantonaki, E. Clinical aspects and molecular diagnostics of skin aging. Clin. Dermatol. 2011, $29,3-14$. [CrossRef]

28. Valenzuela-Rojo, D.R.; López-Cervantes, J.; Sánchez-Machado, D.I. Tilapia (Oreochromis aureus) Collagen for Medical Biomaterials; IntechOpen: London, UK, 2018.

29. Laing, S.; Bielfeldt, S.; Ehrenberg, C.; Wilhelm, K.P. A dermonutrient containing special collagen peptides improves skin structure and function: A randomized, placebo-controlled, triple-blind trial using confocal laser scanning microscopy on the cosmetic effects and tolerance of a drinkable collagen supplement. J. Med. Food 2020, 23, 147-152.

30. Salvatore, L.; Gallo, N.; Natali, M.L.; Campa, L.; Lunetti, P.; Madaghiele, M.; StellaBlasi, F.; Corallo, A.; Capobianco, L.; Sannino, A. Marine collagen and its derivatives: Versatile and sustainable bio-resources for healthcare. Mater. Sci. Eng. 2020, $113,110963$. [CrossRef]

31. Wang, J.-Z.; Dong, X.-B.; Yue, J.-Y.; Zhang, C.-H.; Jia, W.; Li, X. Preparation of substrate for flavorant from chicken bone residue with hot-pressure process. J. Food Sci. 2016, 81, C578-C586. [CrossRef]

32. Ozimek, G.; Jelen, P.; Ozimek, L.; Sauer, W.; McCurdy, S.M. A comparison of mechanically separated and alkali extracted chicken protein for functional and nutritional properties. J. Food Sci. 1986, 51, 749-753. [CrossRef]

33. Hashim, P.; Ridzwan, M.; Bakar, J. Isolation and characterization of collagen from chicken feet'. World Academy of Science, Engineering and Technology, Open Science Index 87. Int. J. Bioeng. Life Sci. 2014, 8, 250-254.

34. Liu, D.; Lin, Y.; Chen, M. Optimum condition of extracting collagen from chicken feet and its characteristics. Asian Australas. J. Anim. Sci. 2001, 14, 1638-1644. [CrossRef]

35. Fonkwe, L.G.; Singh, R.K. Protein recovery from mechanically deboned turkey residue. Trans. ASAE 1994, 37, 527-534. [CrossRef]

36. Hrynets, Y.; Omana, D.A.; Xu, Y.; Betti, M. Comparative study on the effect of acid-and alkaline-aided extractions on mechanically separated turkey meat (MSTM): Chemical characteristics of recovered proteins. Process Biochem. 2011, 46, 335-343. [CrossRef]

37. Venslauskas, K.; Navickas, K.; Nappa, M.; Kangas, P.; Mozūraityrè, R.; Šližytė, R.; Župerka, V. Energetic and economic evaluation of zero-waste fish co-stream processing. Int. J. Environ. Res. Public Health 2021, 18, 2358. [CrossRef] [PubMed] 